\title{
Studies on Zinc Deficiency: Changes in Trace Elements and Enzyme Activities in Tissues of Zinc-deficient Rats*
}

\author{
Ananda S. Prasad, †onald Oberleas, Paul Wolf, and Jerome P. Horwitz \\ WITH THE TECH NICAL ASSISTANCE OF Ray Collins AND \\ JANICE M. VAZQUEZ \\ (From the Departments of Medicine and Pathology, Wayne State University School of \\ Medicine, Detroit, and the Veterans Administration Hospital, Dearborn, and the \\ Detroit Institute of Cancer Research, Detroit, Mich.)
}

Summary. Zinc content of testes, bones, esophagus, kidneys, and muscles was decreased, whereas iron content was increased in the testes of zincdeficient rats compared to restrictedly fed control rats. Histochemical enzyme determinations revealed reduced activities of certain enzymes in the testes, bones, esophagus, and kidneys. In the testes, lactic dehydrogenase (LDH), malic dehydrogenase (MDH), alcohol dehydrogenase (ADH), and NADH diaphorase; in the bones, $\mathrm{LDH}, \mathrm{MDH}, \mathrm{ADH}$, and alkaline phosphatase ; in the esophagus, $\mathrm{MDH}, \mathrm{ADH}$, and $\mathrm{NADH}$ diaphorase; and in the kidneys, MDH and alkaline phosphatase were decreased in zinc-deficient rats compared to restrictedly fed controls. Succinic dehydrogenase (SDH) revealed no significant changes under the conditions of our experiments in various groups of rats that were investigated.

In a "repleted" group of rats, content of zinc in testes and bones increased significantly, compared to the deficient group. The iron content of the testes decreased after repletion with zinc. In the testes, bones, esophagus, and kidneys, the activities of various enzymes increased after repletion with zinc.

Inasmuch as the major manifestations of zinc deficiency syndrome in the rat include growth retardation, testicular atrophy, and esophageal parakeratosis, our results suggest that the content of zinc in the above tissues most likely controls the physiological processes through the formation of zincdependent enzymes.

\section{Introduction}

Raulin (1) in 1869 first showed that zinc was essential for the growth of Aspergillus niger. This was confirmed 40 years later by Bertrand and Javillier (2), and in 1926 its essentiality for higher forms of plant life was established (3). Various

\footnotetext{
* Submitted for publication August 8, 1966; accepted December 15, 1966.

Supported in part by U. S. Public Health Service grants AM 08142-03 and CA 02624, the Jennie Grogan Mendelson Memorial Fund, Detroit General Hospital Research Corporation grant M-16, and Nutrition Foundation grant 331 .

† Address requests for reprints to Dr. Ananda S. Prasad, Dept. of Medicine, Wayne State University School of Medicine, 1400 Chrysler Freeway, Detroit, Mich. 48207.
}

investigators have reported growth retardation and testicular atrophy as a result of zinc deficiency in animal species such as rats $(4,5)$, pigs $(6)$, calves (7), lambs (8), and dogs (9).

In 1961, a group of 11 Iranian adult males were reported to show the following clinical features: iron deficiency anemia, hepatosplenomegaly, short stature, and marked hypogonadism (10). Subsequently, in Egypt, similar patients were studied in detail and were demonstrated to have deficiency of zinc $(11,12)$. It was suggested that growth retardation and hypogonadism in these subjects were possibly related to deficiency of zinc. Zinc supplementation in a number of dwarfs resulted in increased size of the external genitalia; appearance of pubic, axillary, and facial hair; and significant increase in their heights (13). 


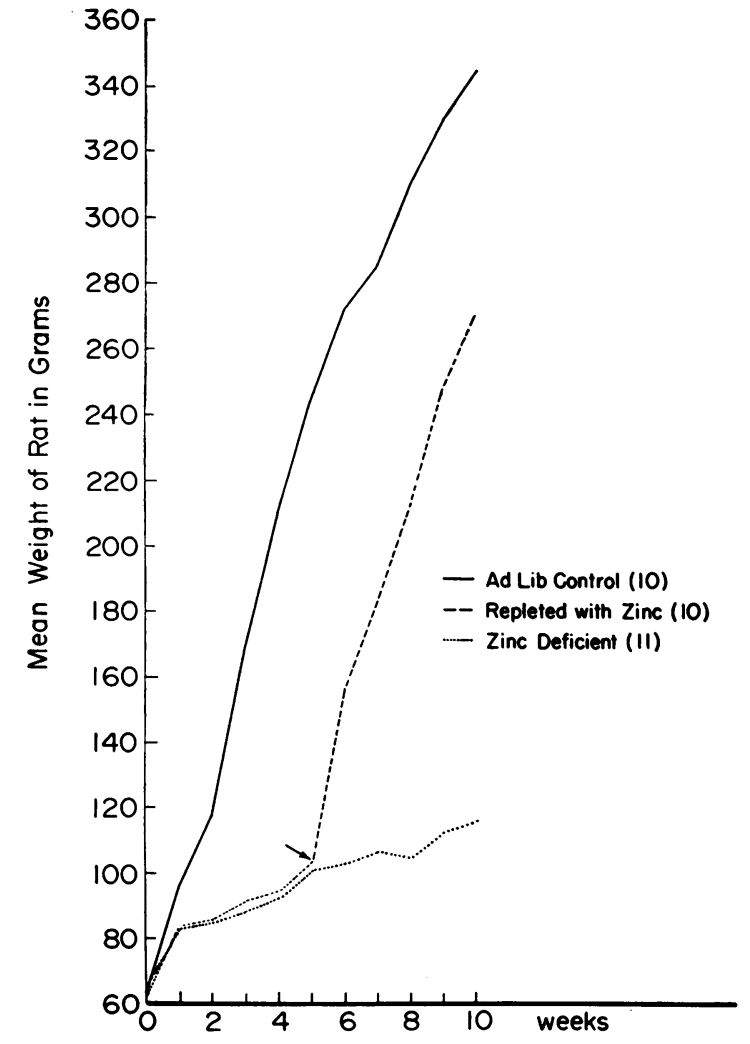

Fig. 1. Growth curves of ad libitum Control rats, ZINC-DEFICIENT RATS, AND RATS ON ZINC-DEFICIENT DIET FOR 5 WEEKS FOLLOWED BY ZINC SUPPLEMENTATION FOR 5 WEEKS ("REPLETED" GROUP). Numbers in parentheses indicate the number of rats in each group. The arrow indicates the time when zinc supplementation was started.

The studies of Vallee (14) on the biochemistry of zinc have established that some enzymes and proteins contain zinc as an essential component and have uncovered a pattern of zinc occurring as an essential component among the nicotinamide dinucleotide-dependent dehydrogenases. Zinc is known to be a constituent of a number of metalloenzymes, which include: carbonic anhydrase, pancreatic carboxypeptidase, liver and yeast alcohol dehydrogenase, alkaline phosphatase, tryptophan desmolase, malic dehydrogenase, glutamic dehydrogenase, lactic dehydrogenase, and probably other pyridine nucleotide-dependent metallodehydrogenases. In addition, zinc increases the activity of a number of other enzymes, apparently as a "cofactor" in a nonspecific manner (14-16). Analyses for various trace metals and enzyme activities in different tissues of zinc-deficient ani- mals have not been carried out extensively in the past. The purpose of this paper is to report results of our analysis of various elements and enzyme activities in tissues of zinc-deficient rats. Our studies revealed that the zinc contents of several tissues were reduced significantly in zincdeficient rats, and, along with this, activities of certain enzymes were also decreased.

\section{Methods}

Weanling male albino rats (Holtzman strain) were maintained in stainless steel cages and given distilled water in glass bottles. Diets were fed ad libitum except in the restricted feeding study, in which the animals were kept in individual cages and the control animals received an amount of diet equal to the mean consumed by the deficient animals daily. The animals were weighed weekly for 6 weeks.

The basal diet (low zinc) contained the following (grams per kilogram) : glucose hydrate (Cerelose), 666; corn oil, 90 ; C-1 assay protein, 150 ; minerals, ${ }^{1} 50$; phytic acid $(54.3 \%), 7.3$; vitamins ; and methionine. ${ }^{2}$ This diet was calculated to contain $12 \%$ crude protein, $1.6 \%$ calcium, $0.6 \%$ inorganic phosphorus, and $1 \%$ phytate. The zinc content was determined to be $10 \mathrm{mg}$ per $\mathrm{kg}$. For the normal (high zinc) diet, $55 \mathrm{mg}$ per $\mathrm{kg}$ of zinc as the carbonate was added to the basal diet.

In the first experiment, 18 rats served as ad libitum controls and 18 received a diet deficient in zinc for 6 weeks. Ten rats received zinc-deficient diet for 3 weeks, after which they received zinc supplement for 2 weeks (repleted group); in the sixth week they were sacrificed for tissue analysis.

In the second experiment, six rats served as restrictedly fed controls and six were made zinc-deficient for 6 weeks.

In another experiment (Figure 1), growth was studied in the following three groups of rats for 10 weeks: $a$ ) ad libitum controls, $b$ ) zinc-deficient rats, and $c$ ) rats on zinc-deficient diet for 5 weeks followed by zinc supplementation for 5 weeks (repleted group).

The animals were sacrificed by cardiectomy after ether anesthesia. The tissues were removed, washed several

1 The following minerals were supplied (grams per kilogram diet) : $\mathrm{CaCO}_{3}, 10.6 ; \mathrm{CaHPO}_{4} \cdot 2 \mathrm{H}_{2} \mathrm{O}, 16.5 ; \mathrm{MgCO}_{3}$, $1.0 ; \mathrm{MgSO}_{4} \cdot 7 \mathrm{H}_{2} \mathrm{O}, 1.2 ; \mathrm{NaCl}, 5.0 ; \mathrm{KCl}, 0.8 ; \mathrm{FePO}_{4}$ (soluble), 1.6; $\mathrm{KH}_{2} \mathrm{PO}_{4}, 12.5 ; \mathrm{MnSO}_{4} \cdot \mathrm{H}_{2} \mathrm{O}, 0.8 ; \mathrm{CuSO}_{4} \cdot$ $5 \mathrm{H}_{2} \mathrm{O}, 0.06 ; \mathrm{A} 1 \mathrm{~K}\left(\mathrm{SO}_{4}\right)_{2} \cdot 12 \mathrm{H}_{2} \mathrm{O}, 0.01 ; \mathrm{KIO}_{3}, 0.03$; $\mathrm{CoCl}_{2} \cdot 6 \mathrm{H}_{2} \mathrm{O}, 0.002 ; \mathrm{NaF}, 0.04$.

2 Vitamins were supplied at the following levels per kilogram diet: vitamin $\mathrm{A}, 20,000 \mathrm{IU}$; vitamin $\mathrm{D}, 3,000 \mathrm{IU}$; menadione, $10 \mathrm{mg}$; $\alpha$-tocopheryl acetate, $30 \mathrm{mg}$; thiamine $\mathrm{HCl}, 16 \mathrm{mg}$; riboflavin, $16 \mathrm{mg}$; pyridoxine $\mathrm{HCl}, 16 \mathrm{mg}$; Ca pantothenate, $40 \mathrm{mg}$; biotin, $0.2 \mathrm{mg}$; folacin, $5 \mathrm{mg}$; cyanocobalamin, $0.05 \mathrm{mg}$; choline chloride, $1,000 \mathrm{mg}$; methionine, $2.0 \mathrm{~g}$. The antioxidant, butylated hydroxyanisole, was supplied at $100 \mathrm{mg}$ per $\mathrm{kg}$. 
TABLE I

Feed efficiency ratio

\begin{tabular}{ccccc}
\hline Rats & $\begin{array}{c}\text { Total } \\
\text { feed } \\
\text { Num- } \\
\text { ber }\end{array}$ & $\begin{array}{c}\text { Mean gain } \\
\text { in 6 weeks }\end{array}$ & $\begin{array}{c}\text { in weight } \\
\text { per rat in } \\
\text { 6 weeks }\end{array}$ & $\begin{array}{c}\text { Feed effi- } \\
\text { ciency ratio* }\end{array}$ \\
\hline $\begin{array}{c}\text { Restrictively fed } \\
\text { control }\end{array}$ & 6 & 1,776 & $68 \pm 8 \dagger$ & $4.4 \pm 0.5 \ddagger$ \\
Zinc-deficient & 6 & 1,801 & $60 \pm 9 \dagger$ & $5.1 \pm 0.5 \ddagger$ \\
\hline
\end{tabular}

* Feed efficiency ratio $=$ feed consumed (grams)/gain in weight (grams). This was calculated for each rat for a 6-week period.

$\dagger$ Mean \pm standard deviation; in comparison of means, p was not significant.

$\ddagger$ Mean \pm standard deviation; in comparison of means, $p$ was $<0.05$.

times with deionized water, and placed in metal free polyethylene containers. The samples were lyophilized ${ }^{3}$ for 3 days. The lyophilized dry weight was taken, and the tissues were placed in micro-Kjeldahl flasks with redistilled nitric acid ${ }^{4}$ and digested until solution was complete. The digested materials were diluted $1: 5$ with deionized water for most analyses. For calcium and magnesium, additional dilutions with solution containing lanthanum were made so that the final concentration of lanthanum was $0.1 \%$ and the $\mathrm{HNO}_{3}$ concentration was $0.1 \mathrm{~N}$. Standards and blanks were prepared with the same concentrations of nitric acid, lanthanum, or both as above. Analyses were performed by atomic absorption spectrophotometry ${ }^{5}$ at the following wave lengths: zinc, 214 ; copper, 325 ; iron, 248 ; calcium, 212 ; magnesium, 285 ; and manganese, $279 \mathrm{~m} \mu$. A detailed procedure for zinc analysis in biological fluids with this instrument has been reported previously (17).

Tissues from different groups of rats were analyzed for enzyme activities histochemically. We studied NADH diaphorase and lactic, malic, alcohol, and succinic dehydrogenases. Small pieces of tissue were frozen in a test tube and immersed in dry ice and acetone at $-65^{\circ} \mathrm{C}$. They were transferred to a Linderstrom-Lang cryostat and cut and maintained at $-25^{\circ} \mathrm{C}$ until ready to be immersed in the substrate. The substrate for $\mathrm{NADH}$ diaphorase consisted of $5 \mathrm{mg} \mathrm{NADH}$ in $12 \mathrm{ml}$ phosphate buffer $(0.2 \mathrm{M}, \mathrm{pH} 7.5)$ and $3 \mathrm{ml}$ of nitro blue tetrazolium (2 $\mathrm{mg}$ per $\mathrm{ml} \mathrm{H}_{2} \mathrm{O}$ ). The substrate solution for lactic dehydrogenase consisted of $5 \mathrm{ml} \mathrm{Ca} \mathrm{L}(+)$-lactate $(0.2 \mathrm{M})$ and $5 \mathrm{mg} \mathrm{NAD}$ in $7 \mathrm{ml}$ Tris buffer $(0.2 \mathrm{M}, \mathrm{pH} 7.4)$, and $3 \mathrm{ml}$ nitro blue tetrazolium ( $2 \mathrm{mg}$ per $\mathrm{ml} \mathrm{H}_{2} \mathrm{O}$ ). The substrate for maliz dehydrogenase consisted of L-malic acid $(0.25 \mathrm{M})$ and $5 \mathrm{mg} \mathrm{NAD}$ in $7 \mathrm{ml}$ Tris buffer $(0.2 \mathrm{M}$, $\mathrm{pH} 7.4)$. The substrate solution for succinic dehydrogenase consisted of $5 \mathrm{ml}$ disodium salt of succinic acid (0.1 $\mathrm{M})$ in $7 \mathrm{ml}$ phosphate buffer $(0.2 \mathrm{M}, \mathrm{pH} 7.5)$ and $3 \mathrm{ml}$ nitro blue tetrazolium ( $2 \mathrm{mg}$ per $\mathrm{ml} \mathrm{H}_{2} \mathrm{O}$ ). The insuba-

3 Virtis mechanically refrigerated Freeze Mobile, Virtis Co., Gardiner, N. Y.

4 G. F. Smith, Columbus, Ohio.

5 Model 303, Perkin-Elmer Corp., Norwalk, Conn., equipped with a model SRL Recorder, E. H. Sargent Co., Detroit, Mich.
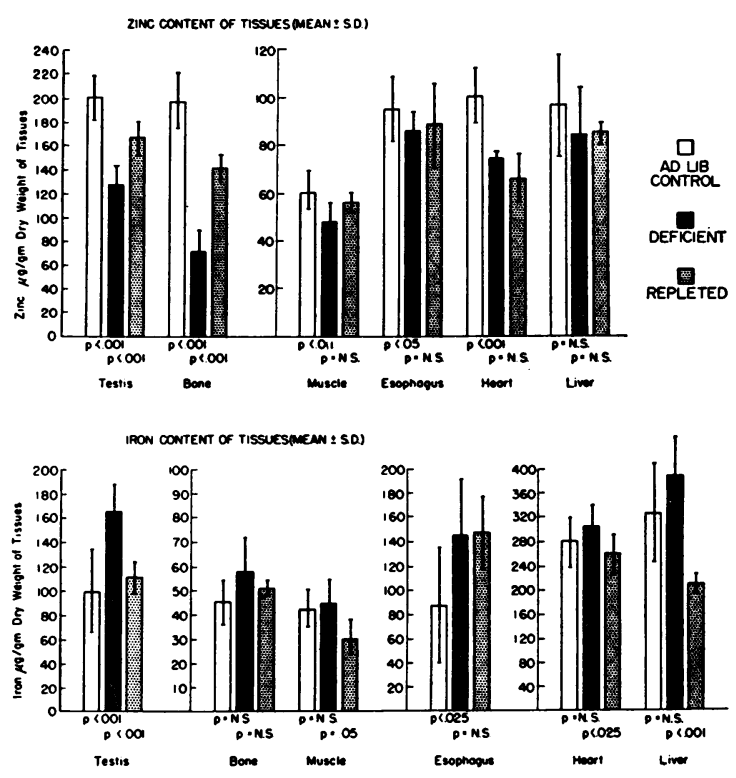

Fig. 2. Zinc AND IRON CONTENTS OF various tissues IN AD LIBITUM CONTROL RATS, ZINC-DEFICIENT RATS, AND A REPLETED GROUP OF RATS (3 WEEKS ON ZINC-DEFICIENT DIET FOLLOWED BY ZINC SUPPLEMENTATION FOR 2 WEEKS). Comparisons of means between ad libitum controls and the deficient group and the deficient group and the repleted group are indicated by the $\mathrm{p}$ values.

tion solution for alcohol dehydrogenase was prepared according to the method published by Pearse (18).

The slides with the affixed tissues were incubated at $25^{\circ}$ $\mathrm{C}$ for 15 minutes for NADH diaphorase and 30 for malic, lactic, and succinic dehydrogenases. The slides for $\mathrm{ADH}$ were incubated for 3 hours. In the presence of appropriate tissue enzymes and added coenzymes, the tetrazolium was reduced to form a colored insoluble formazan, which precipitated at the sites of enzymes in the tissues. The mean formazan intensities were visually evaluated from 1 to 4 plus by three investigators independently.

Alkaline phosphatase reaction was determined histochemically by a method reported by Wolf and co-workers (19). Fresh-frozen and cold acetone-fixed sections were incubated in solutions containing para-toluidinium 5bromo-4-chloro-3-indolyl phosphate or para-toluidinium 5-bromo-6-chloro-3-indolyl phosphate, depending on the desired color of the end product. The solutions were made specific for alkaline phosphatase by varying the $\mathrm{pH}$ of the buffer used for incubation. The incubating solution employed for alkaline phosphatase was as follows: $14.0 \mathrm{ml}(0.1 \mathrm{M})$ Tris buffer ( $\mathrm{pH} 8.4)$ containing $4.0 \mathrm{mg}$ of spermadine trihydrochloride, $1.0 \mathrm{ml}(0.05 \mathrm{M}$ in dimethyl formamide) of substrate (para-toluidinium 5bromo-4-chloro-3-indolyl phosphate or para-toluidinium 5-bromo-6-chloro-3-indolyl phosphate), and $1.0 \mathrm{ml}$ of $0.005 \mathrm{M} \mathrm{MgCl}_{2}$. After incubation for 2 hours the slides were washed briefly in tap water and mounted in glycerol gel for microscopic examination. 
TABLE II

Copper, magnesium, and calcium contents of various tissues obtained from different groups of rats*

\begin{tabular}{|c|c|c|c|c|}
\hline Tissue & Rats & Copper & Magnesium & Calcium \\
\hline \multirow{4}{*}{ Liver } & & & $\mu g / g d r y u$ & \\
\hline & Ad libitum control & $22 \pm 10 \dagger$ & $1,025 \pm 61$ & $183 \pm 23$ \\
\hline & Deficient & $35 \pm 10$ & $1,195 \pm 86$ & $248 \pm 57 \ddagger$ \\
\hline & Repleted & $19 \pm 4$ & $1,227 \pm 102$ & $149 \pm 33$ \\
\hline \multirow[t]{3}{*}{ Bone } & Ad libitum control & $4 \pm 2$ & $4,912 \pm 233$ & $0.16 \pm 0.02 \S$ \\
\hline & Deficient & $5 \pm 3$ & $4,949 \pm 410$ & $0.15 \pm$ \\
\hline & Repleted & $14 \pm 5$ & $5,380 \pm 323$ & $0.17 \pm \quad 0.01$ \\
\hline \multirow[t]{3}{*}{ Testis } & Ad libitum control & $11 \pm 5$ & $1,482 \pm 70$ & $305 \pm 34$ \\
\hline & Deficient & $21 \pm 17$ & $1,577 \pm 213$ & $310 \pm 93$ \\
\hline & Repleted & $17 \pm 9$ & $1,429 \pm 76$ & $357 \pm 124$ \\
\hline \multirow[t]{3}{*}{ Muscle } & Ad libitum control & $9 \pm 3$ & $1,152 \pm 57$ & $347 \pm 158$ \\
\hline & Deficient & $5 \pm 1$ & $1,241 \pm 92$ & $570 \pm 204$ \\
\hline & Repleted & $5 \pm 1$ & $1,227 \pm 87$ & $366 \pm 141$ \\
\hline \multirow{3}{*}{ Esophagus } & Ad libitum control & 0 & $590 \pm 67$ & $1,335 \pm 242$ \\
\hline & Deficient & 0 & $623 \pm 110 \|$ & $1,409 \pm 371$ \\
\hline & Repleted & 0 & $838 \pm 50$ & $1,505 \pm 461$ \\
\hline \multirow[t]{3}{*}{ Heart } & Ad libitum control & $48 \pm 10$ & $1,292 \pm 46$ & $230 \pm 60$ \\
\hline & Deficient & $35 \pm 8 \ddagger$ & $1,363 \pm 160 \|$ & $216 \pm 115$ \\
\hline & Repleted & $30 \pm 13$ & $1,655 \pm 114$ & $277 \pm 53$ \\
\hline
\end{tabular}

* Tissues for analysis were obtained from 12 ad libitum control rats, 12 zinc-deficient rats, and 6 "repleted" rats. All determinations were done in duplicate.

$\dagger$ Mean \pm standard deviation.

$\$$ Mean values significantly different from the controls $(p<0.05)$.

Bone calcium has been expressed in grams per gram dry weight.

II Mean values significantly different from the repleted group $(p<0.05)$.

\section{Results}

Table I shows the feed efficiency ratios of the restrictedly fed control and the zinc-deficient rats. From our data, it is clear that the zinc-deficient rats' feed efficiency was significantly poorer than the controls.

Figure 1 shows the growth curves for the ad libitum controls and the zinc-deficient rats. The growth rate of the zinc-deficient rats was considerably less compared to the ad libitum controls. On repletion with zinc, the growth curve of the deficient group became similar to that of the ad libitum controls.

With the methods employed in our experiments, the recoveries of added zinc ( 0.5 to $3 \mu \mathrm{g}$ ) to the various digested tissues (esophagus, testis, muscle, bone, and liver) were $100 \pm 5 \%$ (S.D.). Recoveries of other added elements $(0.5$ to $1 \mu \mathrm{g})$ to various tissues after digestion were as follows: iron, $99 \pm 4 \%$; copper, $103 \pm 5.6 \%$; magnesium, $103 \pm 3.4 \%$; calcium, $100 \pm 2.8 \%$; and manganese (liver), $100 \pm 5.7 \%$.

Reproducibility was checked in various tissues for all the elements. Coefficients of variation for the various methods were as follows: zinc, $0.3 \%$; iron, $5.1 \%$; copper, $6.5 \%$; magnesium, $0.8 \%$; calcium, $0.5 \%$; and manganese (liver), $2.0 \%$.
The changes in the zinc and iron contents of the various tissues of the ad libitum controls, the zinc-deficient group, and the repleted group are shown in Figure 2. The zinc content of the testes, bones, muscles, esophagus, and heart was decreased in the zinc-deficient rats compared to the ad libitum controls. The zinc content of the liver showed no significant alteration. On repletion with zinc in the deficient group, the zinc content of the testes and bones increased significantly. Copper, magnesium, and calcium contents of the above mentioned tissues showed no significant changes in the three groups, except for copper in the heart, magnesium in the esophagus and the heart, and calcium in the liver (Table II). Copper content of the heart of the deficient group was decreased compared to the ad libitum controls. Magnesium content of the esophagus and heart of the repleted group was higher compared to the deficient rats. The calcium content of the liver was increased in the deficient group compared to the controls. Measurable amounts of manganese were present in the liver only, and this was essentially unaltered in the three groups (ad libitum controls, $12 \pm 4$; deficient rats, $9 \pm 3$; and repleted rats, $7 \pm 1 \mu \mathrm{g}$ per $\mathrm{g}$ dry weight).

Table III shows the results of the analyses of 
TABLE III

Analysis of various tissues for different elements in restrictively fed control rats and zinc-deficient rats*

\begin{tabular}{|c|c|c|c|c|c|c|}
\hline Tissue & Rats & Zinc & Iron & Copper & Magnesium & Calcium \\
\hline Liver & $\begin{array}{l}\text { Control } \\
\text { Deficient }\end{array}$ & $\begin{aligned} 101 & \pm 13 \dagger \\
89 & \pm 12\end{aligned}$ & $\begin{array}{l}351 \pm 64 \\
343 \pm 66\end{array}$ & $\begin{array}{l}\mu g / g d \\
29 \pm 11 \\
15 \pm 4\end{array}$ & $\begin{array}{l}894 \pm 68 \\
859 \pm 51\end{array}$ & $\begin{array}{l}363 \pm 79 \\
252 \pm 84\end{array}$ \\
\hline Bone & $\begin{array}{l}\text { Control } \\
\text { Deficient }\end{array}$ & $\begin{array}{r}168 \pm 8 \\
69 \pm 6 \\
p<.001\end{array}$ & $\begin{array}{l}66 \pm 19 \\
81 \pm 16\end{array}$ & $\begin{array}{ll}3 \pm & 1 \\
2 \pm & 1\end{array}$ & $\begin{array}{l}4,634 \pm 282 \\
4,712 \pm 509\end{array}$ & $\begin{array}{l}0.17 \pm 0.03 \ddagger \\
0.17 \pm 0.02\end{array}$ \\
\hline Testis & $\begin{array}{l}\text { Control } \\
\text { Deficient }\end{array}$ & $\begin{array}{l}176 \pm 12 \\
132 \pm 16 \\
p<.001\end{array}$ & $\begin{array}{l}84 \pm 14 \\
152 \pm 30 \\
p<.001\end{array}$ & $\begin{array}{r}8 \pm 3 \\
10 \pm 1\end{array}$ & $\begin{array}{l}1,254 \pm 338 \\
1,480 \pm 125\end{array}$ & $\begin{array}{l}207 \pm 36 \\
265 \pm 53\end{array}$ \\
\hline Muscle & $\begin{array}{l}\text { Control } \\
\text { Deficient }\end{array}$ & $\begin{array}{r}45 \pm 5 \\
31 \pm 6 \\
p<.01\end{array}$ & $\begin{array}{l}46 \pm 13 \\
35 \pm 14\end{array}$ & $\begin{array}{l}5 \pm 1 \\
4 \pm 1\end{array}$ & $\begin{array}{l}900 \pm 22 \\
841 \pm 45\end{array}$ & $\begin{array}{l}379 \pm 59 \\
380 \pm 69\end{array}$ \\
\hline Esophagus & $\begin{array}{l}\text { Control } \\
\text { Deficient }\end{array}$ & $\begin{array}{c}108 \pm 17 \\
88 \pm 10\end{array}$ & $\begin{array}{l}176 \pm 63 \\
167 \pm 62\end{array}$ & $\begin{array}{l}\mathbf{0} \\
\mathbf{0}\end{array}$ & $\begin{array}{l}624 \pm 12 \\
590 \pm 49\end{array}$ & $\begin{array}{l}1,162 \pm 439 \\
1,086 \pm 174\end{array}$ \\
\hline Heart & $\begin{array}{l}\text { Control } \\
\text { Deficient }\end{array}$ & $\begin{array}{r}73 \pm 16 \\
67 \pm 9\end{array}$ & $\begin{array}{l}165 \pm 53 \\
194 \pm 101\end{array}$ & $\begin{array}{l}29 \pm 13 \\
41 \pm 8\end{array}$ & $\begin{array}{l}1,160 \pm 219 \\
1,533 \pm 64\end{array}$ & $\begin{array}{l}351 \pm 110 \\
447 \pm 116\end{array}$ \\
\hline Lung & $\begin{array}{l}\text { Control } \\
\text { Deficient }\end{array}$ & $\begin{array}{l}81 \pm 3 \\
77 \pm 9\end{array}$ & $\begin{array}{l}200 \pm 64 \\
171 \pm 45\end{array}$ & $\begin{array}{l}20 \pm 4 \\
23 \pm 4\end{array}$ & $\begin{array}{l}691 \pm 51 \\
704 \pm 62\end{array}$ & $\begin{array}{l}476 \pm 114 \\
377 \pm 32\end{array}$ \\
\hline Spleen & $\begin{array}{l}\text { Control } \\
\text { Deficient }\end{array}$ & $\begin{array}{r}105 \pm 13 \\
92 \pm 5\end{array}$ & $\begin{array}{l}614 \pm 71 \\
684 \pm 72\end{array}$ & $\begin{array}{l}62 \pm 14 \\
62 \pm 12\end{array}$ & $\begin{array}{l}1,280 \pm 191 \\
1,165 \pm 100\end{array}$ & $\begin{array}{l}389 \pm 37 \\
373 \pm 64\end{array}$ \\
\hline Kidney & $\begin{array}{l}\text { Control } \\
\text { Deficient }\end{array}$ & $\begin{array}{l}91 \pm 3 \\
80 \pm 3\end{array}$ & $\begin{array}{l}269 \pm 34 \\
275 \pm 32\end{array}$ & $\begin{array}{l}31 \pm 3 \\
48 \pm 13\end{array}$ & $\begin{array}{r}915 \pm 32 \\
1,018 \pm 58\end{array}$ & $\begin{array}{l}290 \pm 54 \\
258 \pm 28\end{array}$ \\
\hline Thyroid & $\begin{array}{l}\text { Control } \\
\text { Deficient }\end{array}$ & $\begin{array}{l}63 \pm 7 \\
58 \pm 9\end{array}$ & $\begin{array}{l}116 \pm 38 \\
170 \pm 70\end{array}$ & $\begin{array}{l}3 \pm 3 \\
9 \pm 5\end{array}$ & $\begin{array}{l}1,487 \pm 238 \\
1,554 \pm 323\end{array}$ & $\begin{array}{l}800 \pm 116 \\
898 \pm 58\end{array}$ \\
\hline Adrenal & $\begin{array}{l}\text { Control } \\
\text { Deficient }\end{array}$ & $\begin{array}{l}66 \pm 15 \\
66 \pm 20\end{array}$ & $\begin{array}{l}327 \pm 145 \\
193 \pm 24\end{array}$ & $\begin{array}{l}0 \\
0\end{array}$ & $\begin{array}{l}297 \pm 41 \\
327 \pm 25\end{array}$ & $\begin{array}{l}327 \pm 45 \\
285 \pm 50\end{array}$ \\
\hline
\end{tabular}

* Tissues for analysis were obtained from six restrictively fed control rats and six zinc-deficient rats. All determinations were done in duplicate. Where the differences between the means were found to be statistically significant, $p$ values have been included.

$\dagger$ Mean \pm standard deviation.

$\ddagger$ Bone calcium has been expressed in grams per gram dry weight.

various elements in the tissues of the restrictedly fed control and the zinc-deficient rats. The zinc content of the bones, testes, muscles, esophagus, and kidneys was decreased and the iron content of the testes increased in the deficient group compared to the restrictedly fed controls. Copper, magnesium, and calcium content of the tissues was not significantly different in the two groups, except for magnesium, which was increased in the heart of the deficient rats. The manganese content of the liver in the two groups was as follows: controls, $14 \pm 3$; and deficient rats, $13 \pm 7 \mu \mathrm{g}$ per g dry weight.

Table IV summarizes the changes in the activities of various enzymes as determined histochemically in the testes, bones, esophagus, and kidneys of the rats representing various groups. The activities of $\mathrm{LDH}, \mathrm{MDH}, \mathrm{ADH}$, and $\mathrm{NADH}$ diaphorase were reduced in the testes of the zinc- deficient rats compared to the control (ad libitum and restrictedly fed). In the repleted group, the activities of the above enzymes in the testes were increased. The activities of $\mathrm{LDH}, \mathrm{MDH}, \mathrm{ADH}$, NADH diaphorase, and alkaline phosphatase in the bones were reduced in the zinc-deficient rats compared to the controls (restrictedly fed and ad libitum). In the repleted group, these enzymes showed increased activities. The activities of $\mathrm{MDH}, \mathrm{ADH}$, and NADH diaphorase in the esophagus were decreased in the zinc-deficient rats compared to the controls. Increased activities of NADH diaphorase in the esophagus were noted in the repleted group. In the kidneys, the activities of MDH and alkaline phosphatase were decreased in the zinc-deficient rats compared to the controls. After zinc supplementation, the activities of LDH, MDH, and NADH diaphorase increased in the kidneys. 
TABLE IV

Summary of histochemical enzyme analysis in testes, bones, esophagus, and kidneys of different groups of rats

\begin{tabular}{|c|c|c|c|c|c|c|}
\hline Tissue & $\begin{array}{c}\text { Lactic de- } \\
\text { hydrogenase }\end{array}$ & $\begin{array}{c}\text { Malic de- } \\
\text { hydrogenase }\end{array}$ & $\begin{array}{l}\text { Alcohol de- } \\
\text { hydrogenase }\end{array}$ & $\begin{array}{l}\text { NADH } \\
\text { diaphorase }\end{array}$ & $\begin{array}{l}\text { Alkaline } \\
\text { phosphatase }\end{array}$ & $\begin{array}{l}\text { Succinic de- } \\
\text { hydrogenase }\end{array}$ \\
\hline \multicolumn{7}{|l|}{ Testes } \\
\hline Ad libitum control & & $\begin{array}{l}4 \\
(4)\end{array}$ & $\begin{array}{l}4 \\
(2)\end{array}$ & 4 & 4 & 2 to 3 \\
\hline $\begin{array}{l}\text { Restrictively fed } \\
\text { control }\end{array}$ & & & & & $\begin{array}{l}(1) \\
1 \\
(4)\end{array}$ & $\begin{array}{l}(3) \\
2\end{array}$ \\
\hline Zinc-deficient & $\begin{array}{l}\text { Trace to } 1 \\
(10)\end{array}$ & $\begin{array}{l}\text { Trace to } 1 \\
\text { (10) }\end{array}$ & $\begin{array}{l}\text { Trace to } 1 \\
(9)\end{array}$ & $\begin{array}{l}\text { Trace to } 1 \\
(9)\end{array}$ & Trace to 1 & $\begin{array}{l}2 \text { to } 3 \\
(10)\end{array}$ \\
\hline Repleted & $\begin{array}{l}3 \text { to } 4 \\
\text { (4) }\end{array}$ & $\begin{array}{l}3 \text { to } 4 \\
(4)\end{array}$ & $\begin{array}{l}3 \\
(2)\end{array}$ & $\begin{array}{l}3 \text { to } 4 \\
\text { (4) }\end{array}$ & $\begin{array}{l}2 \text { to } 4 \\
\text { (4) }\end{array}$ & $\begin{array}{l}2 \text { to } 3 \\
\text { (4) }\end{array}$ \\
\hline \multicolumn{7}{|l|}{ Bones } \\
\hline Ad libitum control & $\begin{array}{l}2 \text { to } 3 \\
\text { (2) }\end{array}$ & $\begin{array}{l}4 \\
(4)\end{array}$ & $\begin{array}{l}3 \text { to } 4 \\
\text { (2) }\end{array}$ & $\begin{array}{l}4 \\
(1)\end{array}$ & $\begin{array}{l}4 \\
(2)\end{array}$ & $\begin{array}{l}1 \text { to } 2 \\
\text { (3) }\end{array}$ \\
\hline $\begin{array}{l}\text { Restrictively fed } \\
\text { control }\end{array}$ & $\begin{array}{l}2 \text { to } 3 \\
\text { (4) }\end{array}$ & $\begin{array}{l}2 \text { to } 3 \\
\text { (4) }\end{array}$ & $\begin{array}{l}2 \text { to } 3 \\
\text { (4) }\end{array}$ & 3 & $\begin{array}{l}3 \text { to } 4 \\
\text { (4) }\end{array}$ & $\begin{array}{l}\text { Trace to } 1 \\
\text { (3) }\end{array}$ \\
\hline Zinc-deficient & $\begin{array}{l}\text { Trace to } 1 \\
\text { (9) }\end{array}$ & $\begin{array}{l}\text { Trace to } 1 \\
(8)\end{array}$ & $\begin{array}{l}\text { Trace to } 1 \\
\text { (9) }\end{array}$ & $\begin{array}{l}\text { Trace to } 1 \\
\text { (6) }\end{array}$ & $\begin{array}{l}1 \text { to } 2 \\
\text { (8) }\end{array}$ & $\begin{array}{l}\text { Trace to } 1 \\
\text { (7) }\end{array}$ \\
\hline Repleted & $\begin{array}{l}2 \text { to } 3 \\
\text { (3) }\end{array}$ & $\begin{array}{l}2 \text { to } 3 \\
\text { (3) }\end{array}$ & (2) & $\begin{array}{l}2 \text { to } 3 \\
\text { (2) }\end{array}$ & $\begin{array}{l}3 \text { to } 4 \\
\text { (2) }\end{array}$ & $\begin{array}{l}2 \text { to } 3 \\
(2)\end{array}$ \\
\hline \multicolumn{7}{|l|}{ Esophagus } \\
\hline Ad libitum control & $\begin{array}{l}2 \text { to } 4 \\
\text { (2) }\end{array}$ & $\begin{array}{l}3 \text { to } 4 \\
\text { (2) }\end{array}$ & $\begin{array}{l}1 \text { to } 2 \\
\text { (2) }\end{array}$ & $\begin{array}{l}3 \text { to } 4 \\
(2)\end{array}$ & & $\begin{array}{l}2 \\
(2)\end{array}$ \\
\hline $\begin{array}{l}\text { Restrictively fed } \\
\text { control }\end{array}$ & $\begin{array}{l}1 \text { to } 2 \\
(4)\end{array}$ & $\begin{array}{l}2 \text { to } 3 \\
\text { (4) }\end{array}$ & $\begin{array}{l}2 \text { to } 3 \\
\text { (4) }\end{array}$ & 3 & $\begin{array}{l}\text { Trace } \\
\text { (2) }\end{array}$ & $\begin{array}{l}\text { Trace to } 1 \\
\text { (4) }\end{array}$ \\
\hline Zinc-deficient & $\begin{array}{l}\text { Trace to } 1 \\
\text { (7) }\end{array}$ & $\begin{array}{l}1 \text { to } 2 \\
(5)\end{array}$ & $\begin{array}{l}1 \text { to } 2 \\
(5)\end{array}$ & $\begin{array}{l}\text { Trace to } 1 \\
(5)\end{array}$ & $\begin{array}{l}\text { Trace } \\
\text { (4) }\end{array}$ & Trace to 1 \\
\hline Repleted & $\begin{array}{l}2 \text { to } 3 \\
(2)\end{array}$ & & & $\begin{array}{l}4 \\
(2)\end{array}$ & (2) & \\
\hline \multicolumn{7}{|l|}{ Kidneys } \\
\hline Ad libitum control & $\begin{array}{l}3 \\
(2)\end{array}$ & $\begin{array}{l}4 \\
(2)\end{array}$ & $\begin{array}{l}1 \text { to } 2 \\
\text { (2) }\end{array}$ & $\begin{array}{l}3 \text { to } 4 \\
\text { (2) }\end{array}$ & & $\begin{array}{l}3 \text { to } 4 \\
(2)\end{array}$ \\
\hline $\begin{array}{l}\text { Restrictively fed } \\
\text { control }\end{array}$ & $\begin{array}{l}2 \text { to } 3 \\
\text { (4) }\end{array}$ & $\begin{array}{l}2 \text { to } 4 \\
\text { (4) }\end{array}$ & $\begin{array}{l}3 \text { to } 4 \\
\text { (4) }\end{array}$ & 3 & $\begin{array}{l}4 \\
(4)\end{array}$ & $\begin{array}{l}3 \text { to } 4 \\
(4)\end{array}$ \\
\hline Zinc-deficient & $\begin{array}{l}1 \text { to } 2 \\
\text { (9) }\end{array}$ & $\begin{array}{l}1 \text { to } 2 \\
\text { (9) }\end{array}$ & $\begin{array}{l}1 \text { to } 2 \\
(5)\end{array}$ & $\begin{array}{l}2 \text { to } 3 \\
(8)\end{array}$ & $\begin{array}{l}2 \text { to } 3 \\
\text { (6) }\end{array}$ & $\begin{array}{l}3 \text { to } 4 \\
(5)\end{array}$ \\
\hline Repleted & $\begin{array}{l}3 \text { to } 4 \\
\text { (4) }\end{array}$ & $\begin{array}{l}3 \text { to } 4 \\
\text { (4) }\end{array}$ & $\begin{array}{l}1 \text { to } 2 \\
\text { (2) }\end{array}$ & $\begin{array}{l}4 \\
(4)\end{array}$ & 3 & $\begin{array}{l}3 \text { to } 4 \\
\text { (3) }\end{array}$ \\
\hline
\end{tabular}

* The intensity of formazan precipitates was judged as follows: $1=$ brown stain but no granules; $2=$ brownish black with few granules; $3=$ black with moderate amount of granules; 4 = black with marked diffuse fine granules. Similar grading was used to evaluate alkaline phosphatase activity. Numbers in parentheses indicate number of rats.

Tissues such as liver, muscle, heart, lung, spleen, thyroid, and adrenal failed to show any consistent changes in the activities of the above mentioned enzymes in the deficient rats. Figures 3 and 4 show representative examples of histochemical enzyme changes in the testis and esophagus.

No consistent change in the activity of SDH (an iron-dependent enzyme) in the testis, bone, esophagus, and kidney was noted in the different groups of rats (Table IV).

The routine light microscopic examination of the tissues fixed in $10 \%$ formalin and sections stained with hematoxylin and eosin showed results that were similar to those reported by Follis, Day, and McCollum (5) and Macapinlac, Pearson, and Darby (20). Section of the testes of the zinc-deficient rats revealed a marked clecrease in the cellularity of all the cells. The esophagus of the zinc-deficient rats showed hyperkeratosis, parakeratosis, and vacuolar changes of the squamous epithelial cells, whereas the kidneys revealed minimal hyaline necrosis of the proximal and distal convoluted tubules.

\section{Discussion}

Since the first description of the effects of deficiency of zinc in rats by Todd, Elvehjem, and Hart (4), histological studies of the rat tissues were reported by Follis and associates (5) and subsequently by Macapinlac and co-workers (20). Besides marked retardation of growth, skin lesions consisting of hyperkeratosis and acanthosis and esophageal lesions showing thickening of stratum corneum and stratum Malpighii with increased 

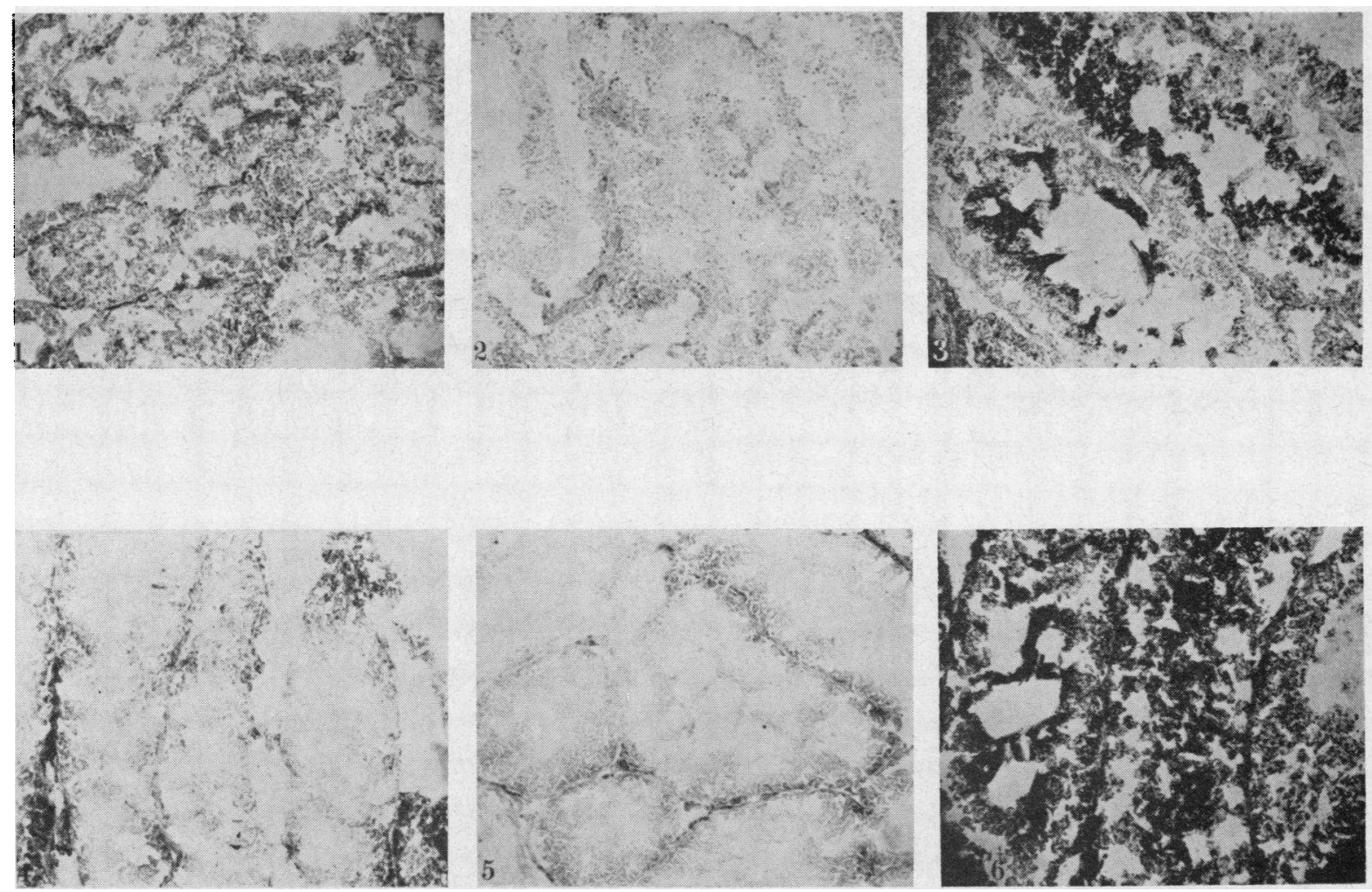

Fig. 3. Sections of rat testes histochemically stained for alcohol dehydrogenase (ADH) and NADH diaPHORASE ACTIVITIES IN DIFFERENT GROUPS OF RATS. $(\times 135) .1=\mathrm{ADH}$ in restrictedly fed control rats; $2=\mathrm{ADH}$ in zinc-deficient rats; $3=\mathrm{ADH}$ in repleted rats; $4=\mathrm{NADH}$ diaphorase in restrictedly fed control rats; $5=\mathrm{NADH}$ diaphorase in zinc-deficient rats; and $6=\mathrm{NADH}$ diaphorase in repleted rats.

numbers of basal layer cells containing hyperchromatic nuclei have been described (5). The testes showed atrophy of the seminiferous tubules, decreased number of cell layers of the germinal epithelium, and the presence of giant cells in the lumen $(20,21)$. Marked reduction in the number of spermatozoa was also noted $(20,21)$. Examination of femoral-tibial joints in the zinc-deficient rats has revealed narrowing of the epiphyses to approximately half the width of those of the controls (20). Follis and associates (5) have noted reduction in the proliferative activity of cartilage cells and a decrease in osteoblastic activity, as manifested by a decrease in metaphyseal bone beneath the cartilage plate. Recent reports indicate that zinc has a specific effect on an organic constituent of bone and plays a part in the sequence of events leading to calcification (22).

The above mentioned reports suggest specific effects of zinc on growth, bones, testes, esophagus, and skin. The results of our studies show that the feed efficiency is reduced in zinc-deficient rats when compared with the restrictedly fed controls. The ad libitum control rats grew at a much greater rate than the zinc-deficient rats. This difference in weight gain can be accounted for partly on the basis of anorexia, which the zinc-deficient rats exhibit; however, from the feed efficiency ratios one may conclude that zinc-deficient rats need more feed to gain an equal amount of weight than rats with sufficient zinc, suggesting metabolic derangements of some type. Diarrhea was not present in the zinc-deficient rats.

Our studies demonstrate that, in the zinc-deficient state, the content of zinc and activities of certain enzymes in the bones, testes, esophagus, and kidneys are decreased. An increase in the zinc content and the activities of the enzymes in the bones and testes were demonstrated after repletion with zinc in our experiments. It therefore seems very likely that the clinical manifestations of zinc deficiency in the rats are related to a de- 

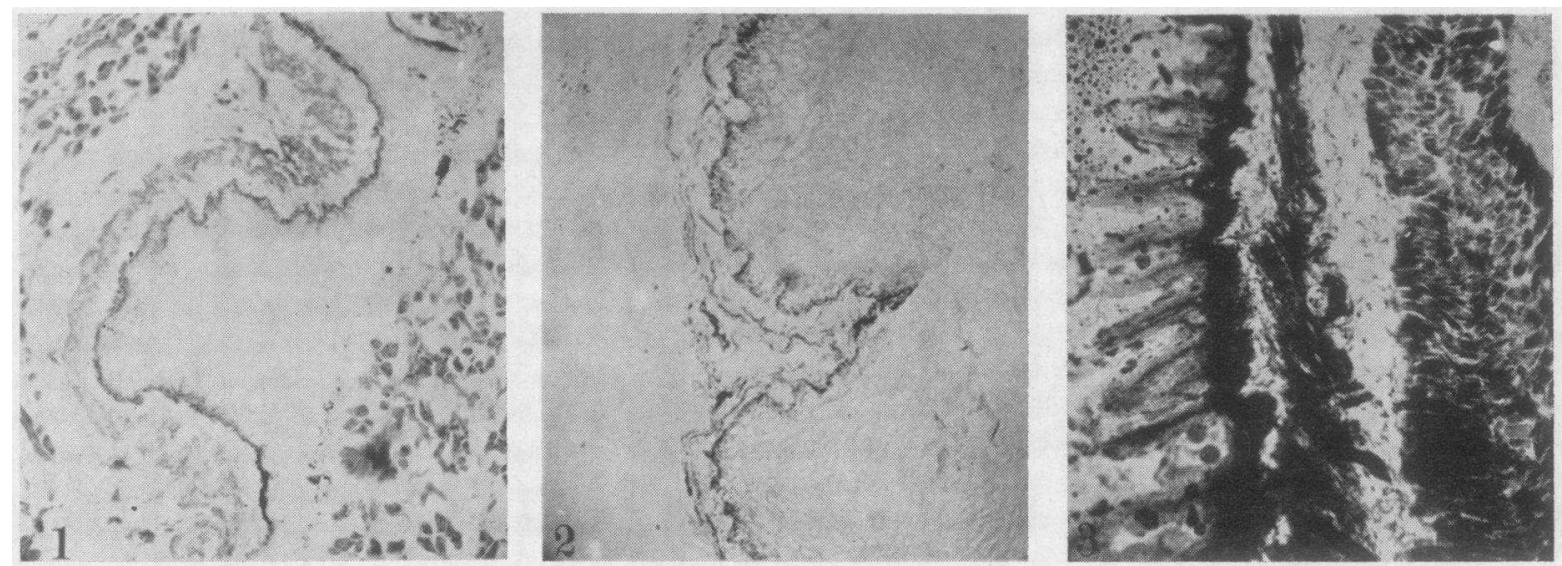

Fig. 4. Sections of RAT esophagus histochemically Stained For NADH diaphorase ACtivity. $(\times 135)$. $1=$ restrictedly fed control rats; $2=$ zinc-deficient rats; and $3=$ repleted rats.

crease in the zinc content of the affected organs, inasmuch as the histological lesions are known to reverse on administration of zinc to the deficient animals (20). Because of the technical difficulties involved, trace metal determinations were not carried out in the skin; therefore, we are unable to correlate the skin lesions with zinc content of the skin in the deficient rats. However, zinc content of hair in animals and man has been reported to decrease during zinc deficiency and increase after repletion with zinc $(13,23)$.

Copper, magnesium, and calcium contents of the tissues that we investigated were not significantly altered in zinc-deficient rats compared to the restrictedly fed controls, except for the magnesium content of the heart, which was increased in the deficient group. The mean iron content of a majority of the tissues in the ad libitum control rats was less than in the zinc-deficient rats; however, in the restrictedly fed controls this difference was not apparent except in the testes. Growth of the body and organs was decreased in the restrictedly fed control and zinc-deficient rats, compared to the ad libitum control rats, in which the organs were larger. Thus, a decrease in the iron content of the tissues of the ad libitum control rats may have been due to dilutional phenomena. A significant increase in the iron content of the testes in the zinc-deficient rats compared to the restrictedly fed controls suggests competition between iron and zinc in the testes. It is unlikely, however, that increased iron content could have been responsible for testicular hypofunction in zinc de- ficiency, since in man zinc deficiency with hypogonadism has been noted with severe iron deficiency anemia (10-13).

The histochemical methods for dehydrogenases depend on the reduction of a water-soluble tetrazolium salt to a water-insoluble formazan by one of the members of the biological oxidation chain. The nitro blue tetrazolium used in our procedure is a sensitive (high oxidation-reduction potential) indicator in dehydrogenase systems and therefore is regarded as the most satisfactory tetrazolium salt for histochemical determination of dehydrogenases (18). It may not be possible to appreciate minor changes in the enzyme activities with this procedure, however. In our experiments marked changes were observed, as shown in the photographs. Since we were interested in investigating a large number of tissues, the histochemical techniques appeared convenient and reliable.

One may speculate that, in a growing cell, there is a series of apoenzymes, each present at some low concentration and, with normal levels of zinc, the apoenzymes combine with metal, forming functional zinc enzymes. At limiting levels of zinc, however, the apoenzymes behave as a series of ligands, each competing for the available zinc ions according to their stability constants. According to this view, the apoenzymes or ligands with high stability constants will be satisfied first, whereas those with low stabilities will not form functional zinc complexes (24). The concentration of free zinc ions will decrease progressively as zinc is diluted by continuing growth, but among the 
apoenzymes or other macromolecular ligands, there will be first one and then perhaps others whose decreasing activities will limit growth. Even when growth stops altogether, we can expect that some of the ligands with the tightest affinities for zinc might still be completely satisfied. This hypothesis can be tested only when the stability constants of at least two such ligands for zinc, including one limiting to growth, have been determined. It must be emphasized that at present there is no evidence to indicate that the enzymes of the rat tissues referred to in this study are zinc metalloenzymes, although they appear to be zinc dependent.

\section{Acknowledgments}

We gratefully acknowledge the technical help of Elizabeth von der Muehll and Norma J. Sfara.

\section{References}

1. Raulin, J. Etudes cliniques sur la végétation. Ann. Sci. nat. botan. Biol. végétale 1869, 11, 93.

2. Bertrand, G., and M. Javillier. Influence du zinc et du manganèse sur la composition minérale de L'aspergillus niger. C. R. Acad. Sci. (Paris) 1911, 152, 1337.

3. Sommer, A. L., and C. B. Lipman. Evidence on indispensable nature of zinc and boron for higher green plants. Plant Physiol. 1926, 1, 231.

4. Todd, W. R., C. A. Elvehjem, and E. B. Hart. Zinc in the nutrition of the rat. Amer. J. Physiol. 1934, $107,146$.

5. Follis, R. H., Jr., H. G. Day, and E. V. McCollum. Histological studies of the tissues of rats fed a diet extremely low in zinc. J. Nutr. 1941, 22, 223.

6. Tucker, H. F., and W. D. Salmon. Parakeratosis or zinc deficiency disease in the pig. Proc. Soc. exp. Biol. (N. Y.) 1955, 88, 613.

7. Miller, J. K., and W. J. Miller. Development of zinc deficiency in Holstein calves fed a purified diet. J. Dairy Sci. 1960, 43, 1854.

8. Ott, E. A., W. H. Smith, M. Stob, and W. M. Beeson. Zinc deficiency syndrome in the young lamb. J. Nutr. 1964, 82, 41.

9. Robertson, B. T., and M. J. Burns. Zinc metabolism and the zinc-deficiency syndrome in the dog. Amer. J. vet. Res. 1963, 24, 997.

10. Prasad, A. S., J. A. Halsted, and M. Nadimi. Syn- drome of iron deficiency anemia, hepatosplenomegaly, hypogonadism, dwarfism and geophagia. Amer. J. Med. 1961, 31, 532.

11. Prasad, A. S., A. Miale, Jr., Z. Farid, H. H. Sandstead, A. R. Schulert, and W. J. Darby. Biochemical studies on dwarfism, hypogonadism and anemia. Arch. intern. Med. 1963, 111, 407.

12. Prasad, A. S., A. Miale, Jr., Z. Farid, H. H. Sandstead, and A. R. Schulert. Zinc metabolism in patients with the syndrome of iron deficiency anemia, hepatosplenomegaly, dwarfism and hypogonadism. J. Lab. clin. Med. 1963, 61, 537.

13. Prasad, A. S. Metabolism of zinc and its deficiency in human subjects in Zinc Metabolism, A. S. Prasad, Ed. Springfield, Charles C Thomas, 1966, p. 250.

14. Vallee, B. L. Biochemistry, physiology and pathology of zinc. Physiol. Rev. 1959, 39, 443.

15. Orten, J. M. Biochemical aspects of zinc metabolism in Zinc Metabolism, A. S. Prasad, Ed. Springfield, Charles C Thomas, 1966, p. 38.

16. $\mathrm{Li}, \mathrm{T} . \mathrm{K}$. The functional role of zinc in metalloenzymes in Zinc Metabolism, A. S. Prasad, Ed. Springfield, Charles C Thomas, 1966, p. 48.

17. Prasad, A. S., D. Oberleas, and J. A. Halsted. Determination of zinc in biological fluids by atomic absorption spectrophotometry in normal and cirrhotic subjects. J. Lab. clin. Med. 1965, 66, 508.

18. Pearse, A. G. E. Histochemistry, Theoretical and Applied. Boston, Little, Brown, 1961, p. 576.

19. Wolf, P. L., J. P. Horwitz, J. Vasquez, J. Chua, M. Noel, M. S. Y. Pak, and C. M. Hasegawa. New method for alkaline and acid phosphatase. Experientia (Basel) in press.

20. Macapinlac, M. P., W. N. Pearson, and W. J. Darby. Some characteristics of zinc deficiency in the albino rat in Zinc Metabolism, A. S. Prasad, Ed. Springfield, Charles C Thomas, 1966, p. 142.

21. Millar, M. J., M. I. Fischer, P. V. Elcoate, and C. A. Mawson. The effects of dietary zinc deficiency on the reproductive system of male rats. Canad. J. Biochem. 1958, 36, 557.

22. Haumont, S., and F. C. McLean. Zinc and the physiology of bone in Zinc Metabolism, A. S. Prasad, Ed. Springfield, Charles C Thomas, 1966, p. 169.

23. Lewis, P. K., Jr., W. G. Hoekstra, and R. H. Grummer. Restricted calcium feeding versus zinc supplementation for the control of parakeratosis in swine. J. Anim. Sci. 1957, 16, 578.

24. Price, C. A. Control of processes sensitive to zinc in plants and microorganisms in Zinc Metabolism, A. S. Prasad, Ed. Springfield, Charles C Thomas, 1966, p. 69. 